\title{
Identification and Characterization of Antioxidant and Bioactive Components of Mirabilis Jalapa and Dracocephalum Moldavica L. Plants
}

\author{
Mohammed. I. Abd El-Aleem, Ahmed, A. Abd El-Rahman and Abdalla .E. El-Hadary \\ Biochemistry Dept., Fac. Agric., Benha University, Egypt \\ Corresponding Author: elhadary.a@fagr.bu.edu.eg
}

\begin{abstract}
This study was conducted Mirabilis Jalapa and Dragonhead leaves and seeds to evaluate bioactive components. Carbohydrates represent the major component in the Mirabilis.J (75.20\%). The content of Dragonhead Lipids and protein $(28.5-23.9 \%)$ was higher than that of Mirabilis.J $(4.5-10.4 \%)$ respectively. Mirabilis.J and Dragonhead oil contains high amounts of unsaturated fatty acids. The unsaturated fatty acids of Mirabilis.J and Dragonhead oil were (79.21 and 88.55\%) of total fatty acids respectively. The major unsaturated fatty acids in Mirabilis.J were linoleic acid (31.48\%) followed by oleic (20.38\%) and Gama linolenic (18.39\%), while, total saturated fatty acids content was $17.87 \%$. Dragonhead seed oil contains also major unsaturated fatty acids were Alfa-linolenic (51.88\%) followed by linoleic $(23.38 \%)$ and oleic acid $(12.16 \%)$. Total phenolic and total flavonoid compounds, scavenging radical effect on 2, 2-diphenylpicrylhydrazyl (DPPH) and ABTS (2,2azino-bis (3-ethlbenzthiazoline-3-sulfonic acid) radical-scavenging activity were investigated .The specific phenolic and flavonoid composition quantification for ethanolic extract were performed by HPLC. presence 21 phenolic compounds in dragonhead ethanolic extract. The highest quantities were, ellagic, benzoic, salycillic, ferulic, iso-ferulic and catechein while in Mirabilis.J ethanolic extract were pyrogallol, catechein, salycillic ,chlorogenic, ellagic and benzoic acid were found as the major phenols. Naringin, kamp.3, (2-p-comaroyl) glucose, luteolin.7glucose, hespirdin, rutin, apig.6arbinose.8.galactose, apigenin.-7 -o-neohes and quercetrin were found as the major flavonoids in dragonhead ethanolic extract however naringin, hespirdin, kamp.3, (2comaroyl) glucose and rutin were found as the major flavonoids in Mirabilis jalapa.
\end{abstract}

Key words: - Mirabilis jalapa, dragonhead, fatty acids, phenolic and flavonoid compounds.

\section{Introduction}

Mirabilis jalapa (family Nyctaginaceae) is a perennial herbal medicinal plant, has along traditional uses. Dried flowers used as a snuff for headaches, fungal infection and root decoction to wash wounds treat skin afflictions. It is used remedy for kidney stones and gallbladder chyluria (Aoki et al., 2008).

The leaves are used as traditional folk medicine in the Brazil to treat inflammatory and painful diseases and as a laxative. The plant used for its antibacterial, antiviral, antifungal, antispasmodic, antitumor, diuretic, hydragogue, anti-oxidative, antimicrobial and anti-nociceptive actions (Kumar et al., 2010).

Dragonhead (Dracocephalum moldavica) plants belong to family Lamiaceae. Also, it is recently introduced to Egypt during the last two decades it is a hardy plant native to regions from Eastern Europe to Siberia. The plant is widely used in folk medicine as pain killer and kidney complains .it is an easy and care free plant best massed in sunny or party shaded areas on well-drained soil (Ismail, 2007) .Dragonhead is used as painkiller for treatment of kidney complains, against toothache and colds as well as ant rheumatism. In addition, dragonhead plant is very attractive to honey bees and this may reduce their mortality when subjected to pesticide-contaminated ground cover. (Dastmalchi et al., 2007)

Chemical analysis of Mirabilis Jalapa leaves showed that many active compounds including alphaamyrins, beta-amyrins, beta-sitosterols, 2- carboxyarabinitol, campesterol, daucosterol, Dglucan, dopamine, hexaconsan1-ol, isobetanin, methyl labronisoflavone, olenolic acid, stigmasterol, tartaric acid, trigonelline, tryptophan and vulgaxanthin (Tinoi et al., 2006)

Dracocephalum moldavica is a source of flavonoids and terpenoids such as luteolin, apigenine, oleanolic acid, ursolic acid, geranial, neral, limonene10 -al and rosmarinic acid and phenolic compounds contribute to antioxidant activity Kakasy et al., (2006) and (Fattahi et al., 2013)

Therefore, the aim of the present study is to assess chemical composition of Mirabilis jalapa and Dracocephalum moldavica, leaves and seeds. Fatty acids composition of seeds oil. Determination of Mirabilis jalapa and Dracocephalum moldavica protein subunits molecular weight by using SDSPAGE. Determination of total phenolic, total flavonoids compounds and antioxidant activity were carried out.

\section{Materials and Methods}

\section{Materials:}

The Mirabilis Jalapa and dragonhead (seeds and leaves) were obtained from Farm Agricultural Research Station, Faculty of Agriculture at Moshtohor, Benha University. Samples were collected in 2017. All chemical used in these experiments were provided from Sigma and Aldrich chemical company of high quality and purity. 
Analytical methods:

Moisture, total lipids, crude protein, ash, total carbohydrate and total fatty acids: were determined according to the method of the Association of Official Analytical Chemists (A.O.A.C., 2005). The total fatty acids obtained from the oil samples were methylated by diazomethane and identified by gas liquid chromatography (GLC). Diazomethane was prepared from methylamine and urea as reported by Vogel (1975).

Preparation of protein isolate from seeds meal: -Extraction with alkaline solution, $\mathrm{pH}$ of protein precipitation and determination of protein subunits molecular weight:

Defatted Mirabilis Jalapa and Dragon head samples were extracted by using $0.02 \mathrm{~N}$ of sodium hydroxide according to the method described by Melnychyn and Wolcott (1971). The $\mathrm{pH}$ of protein precipitation was adjusted to cover $\mathrm{pH}$ ranges from 3.2 to 10.8. Each five grams of the sample was dispersed in the extracting solution for $15 \mathrm{~min}$. The suspension was centrifuged at $10.000 \mathrm{rpm}$ for $15 \mathrm{~min}$. The supernatant was then transferred to a volumetric flask using distilled water and used for protein determination, according to of Lowary et al. (1951). Determination of protein subunits molecular weight by using polyacrylamide gel electrophoresis was preformed according to Laemmli (1970).

Preparation of Mirabilis jalapa and dragonhead leaves extract:

The dried leaves was powdered mechanically and soaked with $80 \%$ ethanol $(1: 10)$ in brown bottles at room temperature $\left(25-30^{\circ} \mathrm{C}\right)$ in dark place for 7 day and mix gently every day. The mixture was filtrated by suction pump in Buchner funnel throw filter paper and concentrated to dryness using rotary evaporator and freeze dry.

\section{Determination of total phenolic and flavonoids compounds}

The concentration of total phenols in all extracts were measured by a UV spectrophotometer (SM1600UV-visSpectrphotometers, Azzota, USA), based on a colorimetric oxidation/reduction reaction as described by Skerget et al. (2005). Total flavonoids content was determined by the method of Ordon et al. (2006).

DPPH (2, 2-diphenylpicryhydrazyl) radicalscavening activity:

The electron donation ability of the obtained extracts was measured by bleaching of the purple colored solution of DPPH according to the method of Hanato et al. (1988).

ABTS (2, 2-azino-bis (3-ethlbenzthiazoline-3sulfonic acid) radical-scavenging activity: $\mathrm{ABTS}^{\circ+}$ radical scavenging activity and adopted of extracts were measured by the $\mathrm{ABTS}^{\cdot+}$ cation decolorization assay as described by $\operatorname{Re} \boldsymbol{e t} \boldsymbol{a l}$. (1999).

\section{HPLC analysis:}

The dried hydrolyzed ethanolic extracts were dissolved in HPLC grade methanol $1.0 \mathrm{mg} / \mathrm{ml}$ ), filtered through sterile $0.22 \mu \mathrm{m}$ Millipore filter and subjected to qualitative and quantitative analysis by using Shimadzu LC-IOA (Kyoto, Japan) HPLC instrument. (Prakash, 2007)

\section{Result and Discussion}

Chemical composition of Mirabilis. $\mathbf{J}$ and Dragonhead leaves and seeds

The chemical composition of mirabilis. $J$ and dragonhead leaves and seeds were determined and reported in table (1).

Oil content in dragonhead leaves and seeds ranges from $3.14 \pm 0.59$ to $28.50 \pm 0.59 \mathrm{~g} / 100 \mathrm{~g}$ dry weight basis whereas that carbohydrate represents the major components in dragonhead seeds and leaves ranged from $35.89 \pm 0.55$ to $71.84 \pm 0.55 \mathrm{~g} / 100 \mathrm{~g}$ dry weight basis. The results showed that protein content ranged from $12.84 \pm 0.22$ to $23.90 \pm 0.22 \mathrm{~g} / 100 \mathrm{~g}$ on dry weight basis in dragonhead leaves and seeds. Generally concluding Dragonhead seeds is considered as good source of protein and lipid.

From the obtained results it could be noticed that carbohydrate represents the major component in the Mirabilis.J (75.20\%).The content of Dragonhead Lipids and protein $(28.5-23.9 \%)$ was higher than of Mirabilis.J $(4.5-10.4 \%)$ respectively.

The accomplished results are in agreement with those reported by Asima et al., (2014), Hanczakakowsti et al., (2009) and Dziki et al., (2013)

Table 1. Chemical composition of Dragonhead and Mirabilis.J leaves and seeds (g/100g dry weight basis).

\begin{tabular}{|c|c|c|c|c|}
\hline \multirow{3}{*}{ Components } & \multicolumn{4}{|c|}{ g/100g dry weight basis } \\
\hline & \multicolumn{2}{|c|}{ Dragonhead } & \multicolumn{2}{|c|}{ Mirabilis.J } \\
\hline & Leaves & Seeds & Leaves & Seeds \\
\hline Moisture & $9.03 \pm 0.09$ & $6.55 \pm 0.09$ & $11.8 \pm 0.09$ & $5.6 \pm 0.09$ \\
\hline Lipids & $3.14 \pm 0.59$ & $28.50 \pm 0.59$ & $2.53 \pm 0.26$ & $4.5 \pm 0.26$ \\
\hline Protein & $12.84 \pm 0.22$ & $23.90 \pm 0.22$ & $6.86 \pm 0.12$ & $10.4 \pm 0.12$ \\
\hline Ash & $3.15 \pm 0.03$ & $5.16 \pm 0.03$ & $3.42 \pm 0.05$ & $4.3 \pm 0.05$ \\
\hline *Carbohydrate & $71.84 \pm 0.55$ & $35.89 \pm 0.55$ & $75.29 \pm 0.69$ & $75.2 \pm 0.69$ \\
\hline
\end{tabular}

*Total carbohydrate $=100-($ protein + fat + moisture + ash $)$ 
Effect of pH on protein isolation from Mirabilis.J and Dragonhead seeds:

Several experiments were carried out in order to establish the proper $\mathrm{pH}$ values required for Mirabilis.J and Dragonhead protein extraction. The obtained results are presented in Fig. (1) from these results it has shown that the maximum protein extraction was achieved at $\mathrm{pH} 11$. On the other hand, results showed that on the acidic $\mathrm{pH}$ range, the percentage of the extracted protein was very lower than alkaline and reached its lowest amount at $\mathrm{pH} 4.0-5.0$ (isoelectric point) in Mirabilis.J and Dragonhead respectively. However, at basic pH (11) the percentage of the extracted protein were found to be $(94.12-94.23)$ from Mirabilis.J and Dragonhead respectively. The solubility of protein increases with increasing the acidity or alkalinity which might be attributed to the increase of repulsive electric forces induced by charges of some sign that might exist on protein molecules (Ozcan, 2000).

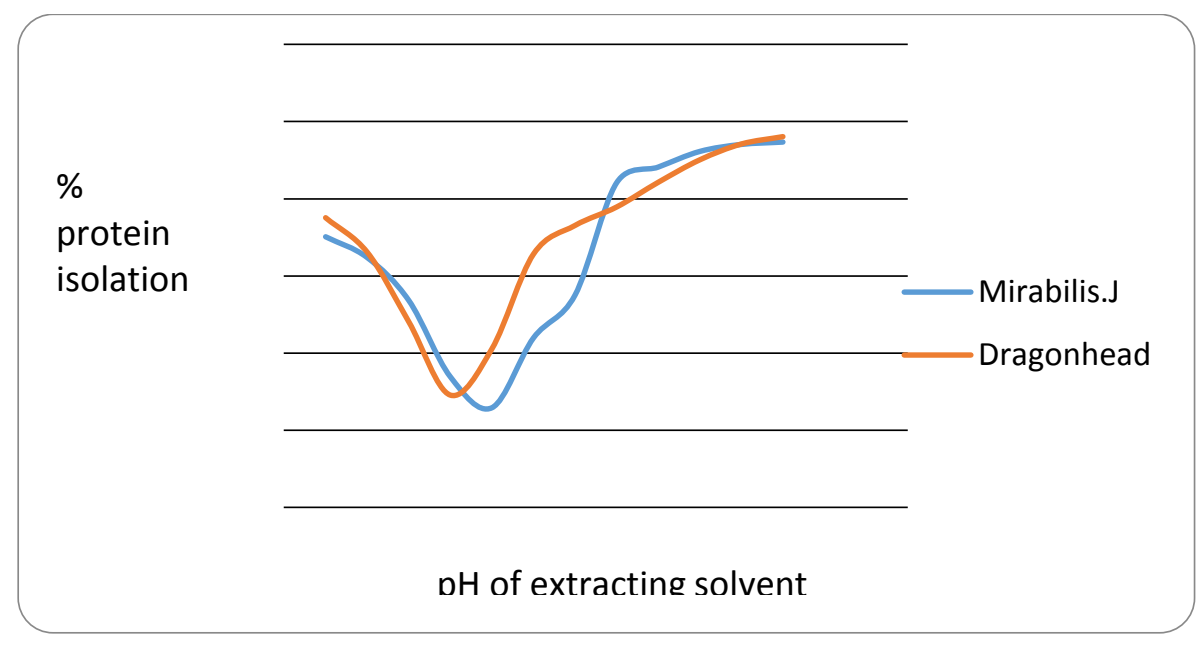

Fig. (1): Effect of $\mathrm{pH}$ on protein isolation from Mirabilis.J and Dragonhead seeds.

Determination of Mirabilis.J and Dragonhead protein subunits molecular weight by using SDSPAGE:

Polyacrylamide Gel Electrophoresis in the presence of detergent Sodium Dodecyl Sulphate
(SDS-PAGE) was used for determining the subunit molecular weights (M.W.) of protein extracted by alkaline solutions from Mirabilis.J and Dragonhead meal.
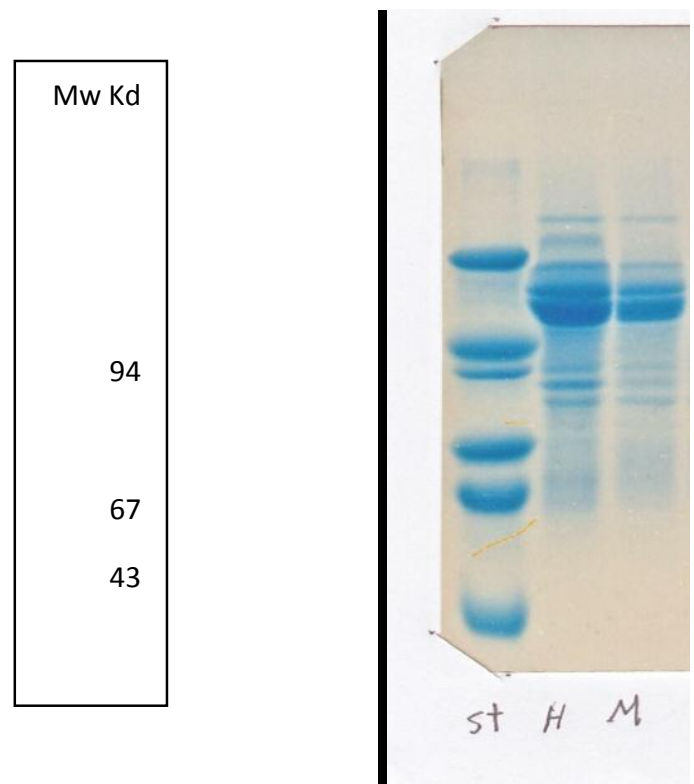

Fig. (2): SDS-PAGE pattern of protein extracts of Mirabilis.J and Dragonhead

St: standard protein

H: Dragonhead protein

M: Mirabilis.J protein 
The obtained results show that the presence of 10 and 9 subunits respectively with molecules ranging from 95.000 to $33.000 \mathrm{KD}$ in the Dragonhead protein and 94.000 to 33.000 in the Mirabilis.J. The achieved results are in agreement with those reported by Rith et al., 2010 found that the Mirabilis.J protein containing of 9 bands of MW86.7 to $13.5 \mathrm{KD}$.

Fatty acids composition of Mirabilis.J and Dragonhead seed oil:

Gas- liquid chromatography was used for the qualitative and quantitative determination of individual fatty acids methyl esters. Fatty acids composition of Mirabilis.J and Dragonhead seeds oil are presented in Table (2)

The obtained results showed that Mirabilis.J and Dragonhead oil contains high amounts of unsaturated fatty acids. The unsaturated fatty acids of Mirabilis.J and Dragonhead oil were (79.21 and $88.55 \%$ ) of total fatty acid respectively.
The major component of unsaturated fatty acids in Mirabilis.J were linoleic acid $(31.48 \%)$ followed by oleic $(20.38 \%)$ and Gama linolenic (18.39\%), while, total saturated fatty acids content was $17.87 \%$. Among the saturated fatty acid, palmitic acid showed as a major percentage $(11.39 \%)$ followed by stearic acids $(3.82 \%)$ in Mirabilis.J seeds.

Dragonhead seed oil contained also major unsaturated fatty acids their value were Alfa-linolenic $(51.88 \%)$, linoleic $(23.38 \%)$ and oleic acid (12.16\%). On the other hand two saturated fatty acid were identified palmitic acid as the major one which reached a value $(5.97 \%)$ followed by stearic acids $(3.14 \%)$.The obtained results are in agreement with those reported by Patel and Patel (1985), Domokos et al., (1994) and Hanczakowski et al., (2009) who found that dragonhead seeds are rich in oil ranged from (18-29\%) this rich in unsaturated fatty acid about $90 \%$.

Table 2. Fatty acids composition of Mirabilis.J and Dragonhead

\begin{tabular}{|c|c|c|}
\hline Fatty acids & Mirabilis.J seeds oil \% & Dragonhead seeds oil \% \\
\hline Lauric $\mathrm{C}_{12: 0}$ & 0.40 & 0.21 \\
\hline Tridecanoic $\mathbf{C}_{13: 0}$ & 0.98 & 0.55 \\
\hline Myristic C14:0 & 0.49 & 0.37 \\
\hline Tetradecenoic C $14: 1$ & 0.22 & 0.17 \\
\hline Palimitic C 16 : 0 & 11.39 & 5.97 \\
\hline Palmitoleic C 16 : 1 & 0.14 & 0.38 \\
\hline Margaric C $17: 0$ & 0.07 & 0.15 \\
\hline Heptadecenoic C17:1 & 0.02 & 0.09 \\
\hline Stearic C18 : 0 & 3.82 & 3.14 \\
\hline Oleic C18: 1 & 20.38 & 12.16 \\
\hline Linoleic C18 : 2 & 31.29 & 23.38 \\
\hline Gamma Linolenic $C_{18:} 3 \omega 6$ & 18.39 & --- \\
\hline Alfa Linolenic $C_{18: 3 \omega 3}$ & 1.72 & 51.88 \\
\hline Archidic $\mathbf{C}_{20}: 0$ & 0.33 & 0.10 \\
\hline Godoleic $\mathrm{C}_{20}$ : 1 & 3.68 & 0.49 \\
\hline Behenic $C_{22}$ : 0 & 0.39 & 0.04 \\
\hline Erucic acid $\mathrm{C}_{22: 1}$ & 3.37 & -- \\
\hline Lignoceric C $24: 0$ & --- & 0.20 \\
\hline Total saturated & 17.87 & 10.73 \\
\hline Total unsaturated & 79.21 & 88.55 \\
\hline
\end{tabular}

Total Phenolic compound, total flavonoids and anti-radical activity of Dragon head and Mirabilis .J leaves extracts:

From the data presented in Table (3) it is clear that the ethanolic extract yield of Dragon head and Mirabilis .J were $22.98 \%$ and $25.75 \%$ respectively. However total phenolic content of Dragon head and Mirabilis .J leaves extract were519.13 and 326.75 mg/GAE extract.

Total flavonoids of dragonhead and Mirabilis .J leaves extract were 34.21 and $27.81 \mathrm{mg} / \mathrm{GAE}$ extract respectively. The accomplished results are good in agreement with those reported by Mohamed et al., (2010) and Mandegary et al., (2014).

Antioxidant activity of the ethanolic extracts:
Ethanolic extracts from Dragonhead and Mirabilis .J leaves showed that strong scavenging activity against DPPH and ABTS radicals Table (3). From the abovementioned data it is clear that samples with low content phenolic compound have lower antioxidant activity. The antioxidant activity of phenolic compounds are to be largely determined by the number of hydroxyl groups on the aromatic ring. The higher number of hydroxyl groups, the greater expected antioxidant activity. These results are agreement with that reported by Dodonné $\boldsymbol{e t} \boldsymbol{a l}$., (2009), Zachariah et al., (2011) and Gill-Miron., (2016). Data presented in table (3) shows antioxidant activity of dragonhead was higher than mirabilis in leaves extracts in both DPPH 87.64\%, 70.09\% and ABTS $82.35 \%, 65.80 \%$ respectively. 
Table 3. Ethanolic extract yield, total phenolic, total flavonoid and antiradical activities of Dragonhead and Mirabilis .J leaves extract:

\begin{tabular}{|c|c|c|c|c|c|}
\hline \multirow{2}{*}{ Material } & \multirow{2}{*}{$\begin{array}{c}\text { Total extract } \\
\%\end{array}$} & \multirow{2}{*}{$\begin{array}{l}\text { Total phenolic } \\
\text { mg / g extract }\end{array}$} & \multirow{2}{*}{$\begin{array}{c}\text { Total } \\
\text { flavonoids } \\
\text { mg / g extract } \\
\end{array}$} & \multicolumn{2}{|c|}{$\%$ Antiradical activity } \\
\hline & & & & DPPH & ABTS \\
\hline $\begin{array}{l}\text { Dragonhead } \\
\text { leaves }\end{array}$ & $22.98 \pm 1.45$ & $519.13 \pm 0.14$ & $34.21 \pm 0.95$ & $87.64 \pm 1.51$ & $82.35 \pm 1.17$ \\
\hline $\begin{array}{l}\text { Mirabilis. J } \\
\text { Leaves }\end{array}$ & $25.75 \pm 1.34$ & $326.75 \pm 0.19$ & $27.81 \pm 1.17$ & $70.09 \pm 1.43$ & $65.80 \pm 1.31$ \\
\hline
\end{tabular}

Identification of antioxidant components in Dragonhead and Mirabilis. J leaves ethanolic extract by HPLC:

Data presented in Table (4 and 5) showed the chemical constituents of the ethanolic extract of dragonhead and Mirabilis. J leaves.

The results in table (4) revealed the presence 21 phenolic compounds in dragonhead ethanolic extract. The highest quantities were, ellagic (1443.74mg/100g), benzoic $(577.33 \mathrm{mg} / 100 \mathrm{~g})$, salycillic $(576.77 \mathrm{mg} / 100 \mathrm{~g})$, ferulic $(359.9 \mathrm{mg} / 100 \mathrm{~g})$, iso-ferulic $\quad(233.91 \mathrm{mg} / 100 \mathrm{~g}), \quad$ catechein (195.02mg/100g), P-OH-benzoic (179.45 mg/100g), caffeine $(175.29 \mathrm{mg} / 100 \mathrm{~g})$, and pyrogallol (115.53mg/100g).

The results in table (5) revealed the presence 15 flavonoid compounds in dragonhead leaves ethanolic extract. The highest quantities were naringin ( 3331.73 mg / $100 \mathrm{~g}$ ), kamp.3, ( 2-p-comaroyl ) glucose ( $2685.11 \mathrm{mg} / 100 \mathrm{~g}$ ) , luteolin.7 glucose ( 1582.36 $\mathrm{mg} / 100 \mathrm{~g}$ ) hespirdin $(1395.9 \mathrm{mg} / 100 \mathrm{~g}$ ) , rutin ( 394.70mg / $100 \mathrm{~g} \quad$ ) , Apig.6arbinose.8.galactose $(342.18 \mathrm{mg} / 100 \mathrm{~g})$, apigenin.-7 -oneohes $(316.9 \mathrm{mg} / 100 \mathrm{~g})$ and quercetrin ( $289.90 \mathrm{mg} / 100 \mathrm{~g})$.

The results in table (4) revealed the presence 21 phenolic compound in Mirabilis.J ethanolic extract .The highest quantities were pyrogallol (764.91mg/100g), catechein $\quad(542.38 \mathrm{mg} / 100 \mathrm{~g})$, salycillic (149.07 $\mathrm{mg} / 100 \mathrm{~g})$, chlorogenic (89.68 $\mathrm{mg} / 100 \mathrm{~g})$, ellagic $(73.89 \mathrm{mg} / 100 \mathrm{~g})$ and benzoic (73.10mg/100g).

The results in table (5) revealed the presence 15 flavonoid compounds in Mirabilis.J leaves ethanolic extract. The highest quantities were naringin $(470.09 \mathrm{mg} / 100 \mathrm{~g})$, hesperidin $(335.18 \mathrm{mg} / 100 \mathrm{~g})$, kamp.3, (2comaroyl) glucose (197.76mg/100g) and rutin $(172.57 \mathrm{mg} / 100 \mathrm{~g})$. The results are good in agreement with those reported by Saeidnia et al., (2005), Dastmalchi et al., (2007), Popova et al .,(2008), Mohamed et al., (2010), wang and Dai, (2012), and Liqi et al., (2016).

Table 4. Phenolic compounds of dragon head and Mirabilis J. leaves ethanolic extracts analyzed by HPLC

\begin{tabular}{clcc}
\hline phenolic compounds & Dragon head $\mathbf{m g} / \mathbf{1 0 0} \boldsymbol{g}$ & Mirabilis .J $\mathbf{m g} / \mathbf{1 0 0 g}$ \\
\hline 1 & Gallic & 13.73 & 7.45 \\
2 & Pyrogallol & 115.53 & 764.91 \\
3 & 4-aminobenzoic & 13.62 & 23.05 \\
4 & Protocatchuic & 79.65 & 58.27 \\
5 & Catechein & 195.02 & 542.38 \\
6 & Chlorogenic & 90.88 & 89.68 \\
7 & Catechol & 108.53 & 64.99 \\
8 & Caffeine & 175.29 & 58.19 \\
9 & p-OH-benzoic & 179.45 & 10.83 \\
10 & Caffeic & 28.11 & 5.70 \\
11 & Vanillic & 27.23 & 17.89 \\
12 & P-coumaric & 72.72 & 2.24 \\
13 & Ferulic & 359.90 & 12.83 \\
14 & Ios-ferulic & 233.91 & 13.95 \\
15 & Ellagic & 1443.74 & 73.89 \\
16 & Alpha-coumaric & 26.96 & 0.60 \\
17 & Benzoic & 577.33 & 73.10 \\
18 & Salycillic & 576.77 & 149.07 \\
19 & 3,4,5methoxycinnamic & 47.63 & 15.29 \\
20 & Coumarin & 67.95 & 9.65 \\
21 & Cinnamic & 10.93 & 5.72 \\
\hline
\end{tabular}


Table 5. Flavonoids compounds of dragon head and Mirabilis J. leaves ethanolic extracts analyzed by HPLC

\begin{tabular}{llcc}
\hline & \multicolumn{1}{c}{ Flavonoids } & dragon head $\mathbf{~ g o / 1 0 0 g}$ & Mirabilis .J $\mathbf{m g} / \mathbf{1 0 0 g}$ \\
\hline 1 & A Pig.6-arbinose 8- galactose & 342.18 & 42.59 \\
2 & A Pig.6- rhamnose 8- glucose & 173.12 & 52.73 \\
3 & Luteolin 7-glucose & 1582.36 & 64.80 \\
4 & Naringin & 3331.73 & 470.09 \\
5 & Rutin & 394.70 & 172.57 \\
6 & Hespirdin & 1395.59 & 335.18 \\
7 & Apigenin.7 o-neohes & 316.90 & 16.13 \\
8 & Quercetrin & 289.90 & 66.14 \\
9 & Quercetin & 24.57 & 9.89 \\
10 & Kamp.3(2-p-comaroyl)glucose & 2685.11 & 197.76 \\
11 & Naringenin & 119.20 & 43.38 \\
12 & Kampferol & 9.45 & 4.61 \\
13 & Acacetin neo.rutinoside & 132.02 & 20.65 \\
14 & Hespirtin & 114.28 & 29.85 \\
15 & Apegnin & 75.84 & 11.46 \\
\hline
\end{tabular}

\section{Conclusion}

In conclusion, the present study confirm that leaves and seeds of dragon head and Mirabilis .J plant are rich source in some important phytochemical compounds. The ethanolic extract is highly valuable source of natural antioxidant and showed the presences of different bioactive compounds with high antioxidant activity. Further research should be addressed on the application of using leaves extracts of dragon head and Mirabilis .J as natural agent protect against per-oxidative damage in living systems related to diabetic, aging and carcinogenesis

\section{References}

A.O.A.C. (2005): Official methods of analysis of Analytical "18 th"ED. Association of Official Analytical Chemists, Gaithersburg, Maryland, U.S.A.

Aoki, K.; Cortés, A. R.; Del Carmen Ramirez, M.; Gómez-Hernández, M., and López-Muñoz, F. J. (2008). Pharmacological study of antispasmodic activity of Mirabilis jalapa Linn flowers. Journal of ethnopharmacology, 116(1), 96-101.

Asima, G.; Anupam, N. and Banerjl, J. (2014). Chemical characterization of seed proteins of Mirabilis.J. Journal of food properties .17(3):559569.

Dastmalchi, K.; Dorman, H. D.; Koşar, M. and Hiltunen, R. (2007). Chemical composition and in vitro antioxidant evaluation of a water-soluble Moldavian balm (Dracocephalum moldavica L.) extract. LWT-Food Science and Technology, 40(2), 239-248.

Dodonné, S.; Vitrac, X.; Coutiere, P.; Woillez, M. and Mérillon, J. M. (2009). Comparative study of antioxidant properties and total phenolic content of 30 plant extracts of industrial interest using DPPH, ABTS, FRAP, SOD, and ORAC assays. Journal of agricultural and food chemistry, 57(5), 17681774.

Domokos, J.; Peredi, J. and Halasz-Zelnik, K. (1994). Characterization of seed oils of dragonhead (Dracocephalum moldavica L.) and catnip (Nepeta cataria var. citriodora Balb.). Industrial Crops and Products, 3(1-2), 9194.

Dziki, D.; Miś, A.; Gladyszewska, B.; Laskowski, J.; Kwiatkowski, S. and Gawlik-Dziki, U. (2013). Physicochemical and grinding characteristics of dragonhead seeds. International Agrophysics, 27(4), 403-408.

Fattahi, M.; Nazeri, V.; Torras-Claveria, L.; Sefidkon, F.; Cusido R. $M$ and Zamani, Z. (2013). A new biotechnological source of rosmarinic acid and surface flavonoids: Hairy root cultures of Dracocephalum kotschyiBoiss. Industrial Crops and Products, 5: 256-263.

Gill-Miron, A. (2016). Antigen toxic and antioxidant of polyphenolic extract from dracocephalum moldavica L. Industrial Crops and Products, 79:248-257.

Hanato, T.; Kagawa, H.; Yasuhara, T. and Okuda, T. (1988).two new flavonoids and other constituents in licorice root: Their relative astringency and radical scavenging effects. Chemical \& pharmaceutical bulletin 36(6):2090-7.

Hanczakowski, P.; Szymczyk, B.; Kwiatkowski, S. and Wolski, T. (2009). Composition and nutritive value of protein of Moldavian balm seeds (Dracocephalum moldavica L.). Roczniki Naukowe Zootechniki, 36(1), 55-61.

Ismail, S. E. (2007). Comparison study between bio and mineral fertilization of dragonhead plant on yield and volatile oil (Doctoral dissertation, Ph. D. Thesis, Fac. Agric. Moshtohor Benha Univ. Egypt). 
Kakasy, A.; Füzfai, Z.; Kursinszki, L.; MolnárPerl, I. and Lemberkovics, É. (2006). Analysis of non-volatile constituents in Dracocephalum species by HPLC and GCMS. Chromatographia, 63(13), S17-S22.

Kumar, V. K.; Sankar, N. R.; Ramya, S.; Sahaja, R. V.; Saritha, K.; Reddy, K. G. and Naidu, N. V. (2010). Phytochemical screening and antimicrobial activity of the leaf extract of Mirabilis jalapa against pathogenic microorganisms. International Journal of Phytomedicine, 2(4).

Laemmli, U.K. (1970). Cleavage of structural protein during the assembly of the head of bacteriophage T4. J. Nutr., 227: 680-685.

Liqi ,L; Han L; Liu, J.; Liu, W; Feng, F; Zhang, J and Xie, N (2016): Chemical constituents and quality control of two Dracocephalum species based on high-performance liquid chromatographic fingerprints coupled with tandem mass spectrometry and chemometrics. Journal of separation science 39(21):4071-4085.

Lowary, O.J.; Rosebrough, N.J.; Parr, A.L. and Randall, R.J. (1951). Protein measurement with the Folin phenol reagent. J. Biol. Chem., 193: 265275.

Mandegary, A.; Soodi, M.; Sharififar, F. and Ahmadi, S. (2014). Anticholinesterase, antioxidant, and neuroprotective effects of Tripleurospermum disciforme and Dracocephalum multicaule. Journal of Ayurveda and integrative medicine, 5(3), 162.

Melnychyn, P. and Wolcott, J.M. (1971). Isolated soy protein. U.S. Patent. 3:630-753.

Mohamed, H.; Raoudha.J and Moncef .N. (2010). GC /MC analysis and antioxidant and antimicrobial activities various solvent extracts from Mirabilis. Jalapa. J.Homepage process Biochemistry 45; 1486-1493.

Orden, J.D.; Gomez, M.A., and Vattuone, M.I. (2006). Antioxidant activities of sechim edule (Jacp).Swarez extracts.Food Chem97:452-458.

Ozcan, M (2000): Composition of some (prunus armeniaca) kernels grown in turkey. Acta Alimentaria 29:289-293.

Patel R. G. and Patel V. S (1985): Studies on Mirabilis jalapa (Four O'clock Plant) Seed Oil. Fette seifen Anstrichm 87:7-9.
Popova, O. I.; Nikitina, A. S. and Markova, O. M. (2008). Studies of iridoids from Dracocephalum moldavica cultivated in the Stavropol Region. Pharmaceutical Chemistry Journal, 42(6), 351-353.

Prakash A. (2007) Assessing bias in experiment design for large scale mass spectrometry-based quantitative proteomics. Mol Cell Proteomics 6(10):1741-8

Re, R.; Pellegrini, N.; Proteggenete, A.; Pannala, A.; Yang, M. and Rice-Evans, C. (1999): Antioxidant activity applying an improved ABTS radical cation decolorization assay. Free Radic. Biol.Med, 26:1231-1237.

Rith, R; Parkpimol, U; Tulaya, $\mathbf{P}$ and Prapan .S. (2010). Proteins from Mirabilis $J$ possess anticancer activity via Apoptotic pathway.J Health Res, 24(4):161-165.

Saeidnia, S.; Gohari, A. R.; Ito, M., Kiuchi, F., and Honda, G. (2005). Bioactive constituents from Dracocephalum subcapitatum (O. Kuntze) Lipsky. Zeitschrift für Naturforschung C, 60(1-2), 22-24.

Skerget, M.; Kotnik, P.; Hadolin, M.; RiznerHras, A.; Simonic, M. and Kenze, Z. (2005).Phenols, proanthocyanidins, flavones and flavonols in some plant materials and their antioxidant activities. Food Chem., 89:191-198.

Tinoi, J.; Rakariyatham, N. and Deming, R. L. (2006). Determination of major carotenoid constituents in petal extracts of eight selected flowering plants in the north of Thailand. Chiang Mai J Sci, 33(2), 327-334.

Vogel, A.I. (1975). A text book of practical organic chemistry $3^{\text {rd }}$ ed. English language book. Society and Longman's group Ltd.

Wang, X. H. and Dai, J. T. (2012). Antioxidant Activities of Mirabilis jalapa L. Seed Epicarp Extract. In Advanced Materials Research (Vol. 550, pp. 1768-1772). Trans Tech Publications.

Zachariah, S. M.; Aleykutty, N. A.; Viswanad, V.; Jacob, S. and Prabhakar, V. (2011). In-vitro antioxidant potential of methanolic extracts of Mirabilis jalapa Linn. Free Radicals and Antioxidants, 1(4), 82-86. 


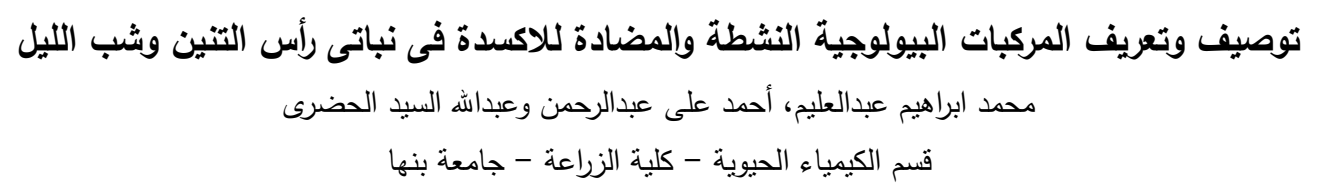

Corresponding Author: elhadary.a@fagr.bu.edu.eg

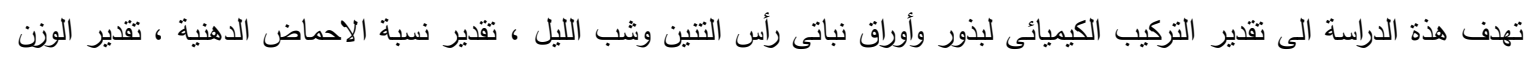

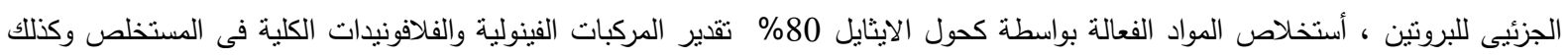

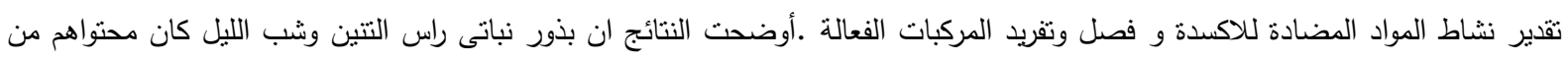

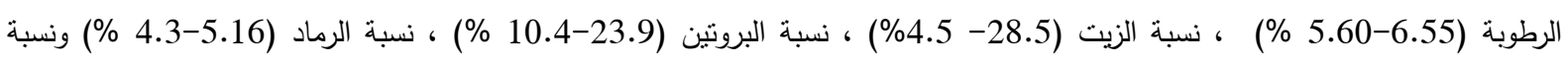

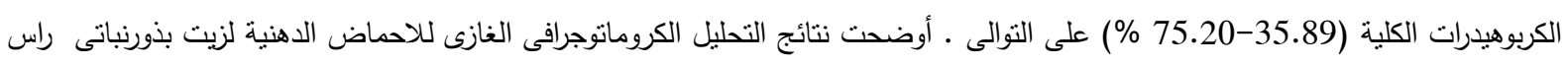

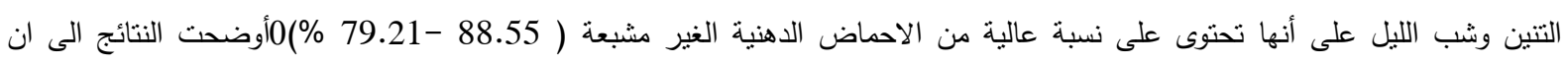

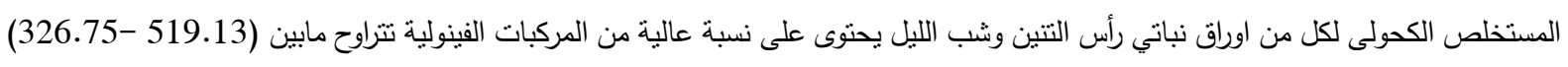

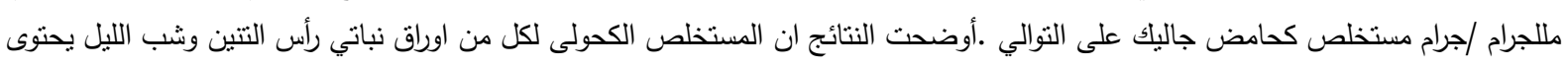

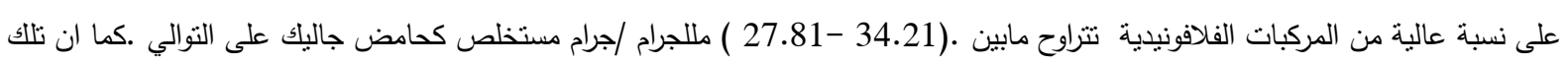

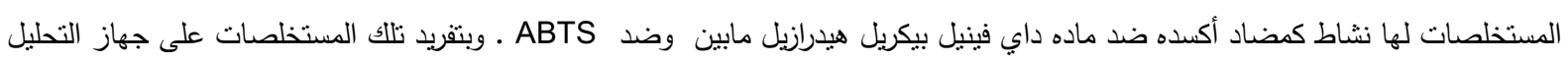

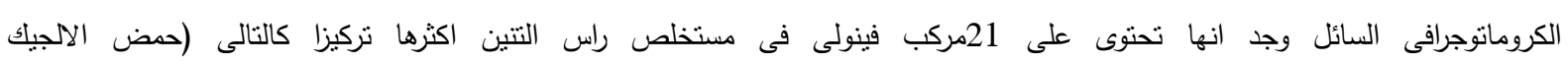

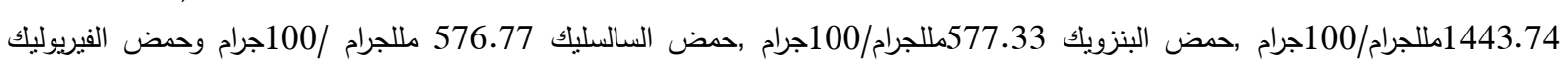

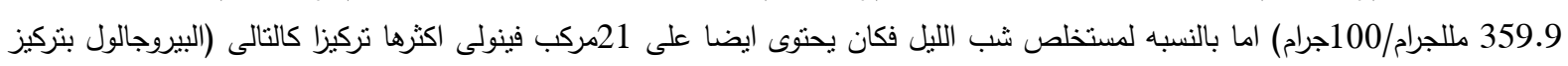

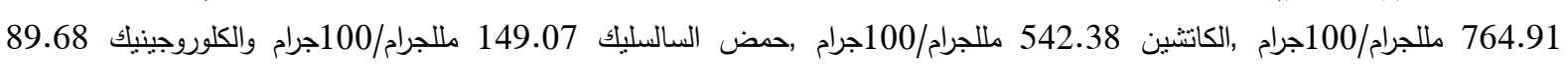

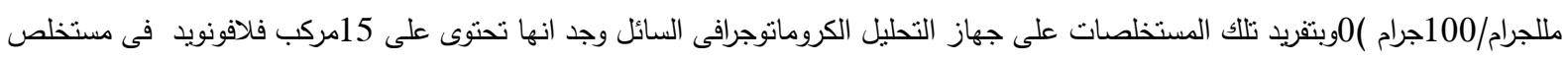

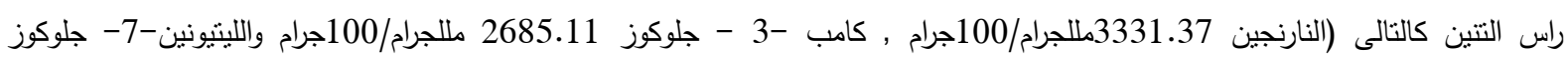

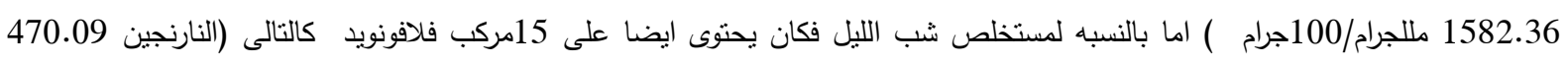

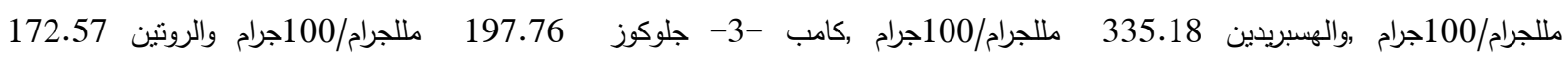
ملاجرام/100جرام ). الكلمات الدالة:- شب الليل ، رأس التتين ، الاحماض الدهنية ، المركبات الفينولية والفلافونيدية 